\title{
Quantifying Physical and Economic Losses of African Indigenous Vegetable Solanum aethiopicum Along the Commercial Supply Value Chain
}

\author{
Kasharu $^{1}$ A.K., E. B. Kizito ${ }^{2}$, M. Masanza ${ }^{2}$, J. Jjagwe ${ }^{3}$ A. Namutebi ${ }^{4}$ \\ 1.CHAINUGANDA, P.O. Box 14364, Mengo Kampala \\ 2Uganda Christian University, Department of Agriculture and Biological Sciences P.O. Box 4, Mukono Uganda \\ 3 .FARM GAIN LTD, P.O. Box 21717, Kampala \\ 4. Makerere University P.O. Box School of Food Science and Nutrition, P.O. Box 7062, Kampala
}

This paper is based on research work done by the authors on African Indigenous vegetables with financial support from the European Union and Forum for Agricultural Research in Africa (FARA) through its Promoting African \& European Partnerships in Agricultural Research \& Development (PAEPARD). This is part of the outputs of the project entitled "Enhancing nutrition security and incomes through adding value to indigenous vegetables in East and Central Uganda".

\section{Abstract}

This study presents results of a research that was conducted in Uganda to expound the issues of Solanum aethopicum (Nakati) value chain supply, physical and economic quantification of losses in the supply chain. Specifically the study was designed to; (i) identify and map the value chain actors of an indigenous leafy vegetable S. aethiopicum production and marketing and (ii) quantify the physical losses along the S. aethiopicum vegetable supply chain and (iii) estimate the economic losses along the $S$. aethiopicum vegetable supply chain.A Participatory Rural Appraisal (PRA) was conducted at Namulonge, Kabanyoro, Busukuma and Zirobwe villages on $7^{\text {th }}$ August 2016, $9^{\text {th }}$ August 2016, $10^{\text {th }}$ August 2016 and $12^{\text {th }}$ August 2016, respectively with the farmers to understand the S. aethiopicum actors' perception of value chain vegetable losses and mitigating solutions. At each supply chain stage namely field, transit, wholesale and retail. The losses were expressed as difference of the weight of vegetables that entered each stage and weighed again when the value adding stage is completed which became the quantity that enters the subsequent stage, thus the losses were determined as a percentage of those that never went to market in relation to the total potential from the field.The value chain actor mapping has revealed a short a short value chain with a number of value chain actors namely; 60 input suppliers, 40 farmer groups, 42 wholesalers, 48 retailers, 2 processors and 61 transporters. With the exception of agro input supply node which handle pesticides, the rest of the actors handle fresh leafy vegetables that are prone to heavy weight losses due to wilting, rotting and transit contamination. The study further indicated that the physical quantities of S. aethopicum harvested varied in different farms, nonetheless, on average $1473.3 \mathrm{kgs}$ per acre of S. aethopicum is harvested and of the harvested vegetables, $69.4 \mathrm{kgs}$ and $73.7 \mathrm{kgs}$ get lost in the field and marketing process, respectively. This translates into S. aethopicum vegetable losses of $13.3 \%$ and $5.2 \%$ in the field and market points, respectively. Most of this loss occurred on-farm with $13.3 \%$ of the harvested crop not entering the commercial-supply chain followed by retail level, $3.5 \%$ losses and least at wholesale level of $1.7 \%$. In terms of economic losses, sale of $S$. aethopicum earned farmers on average 567,233 Shs per acre, sizeable revenue of $26,700 \mathrm{Shs}$ and $53,192 \mathrm{Shs}$ get lost in the field and marketing process, respectively. This is equivalent to $S$. aethopicum revenue losses of $18 \%$ and $35.9 \%$ in the field and market points, respectively. Overall, 79,892 Shs of S. aethopicum revenues was lost in the commercial supply chain constituting $53.9 \%$ of the losses. Break down of revenue losses showed that at farm level, the loss is $18 \%$, at wholesale level the losses are $10.2 \%$ and at retail level losses are $25.7 \%$.It therefore can be concluded that there is a high physical and economic losses of leafy S. aethopicum vegetables at different stages in the supply chain. More research efforts could be focussed on technologies that reduce post-harvest losses such as drying and minimal processing technologies at farm level where greatest losses are experienced.

Keywords: African indigenous vegetables, supply chain, economic loss, physical losses

DOI: $10.7176 / \mathrm{JESD} / 10-2-08$

\subsection{Background}

Uganda is home to hundreds of African Indigenous Vegetables (AIVs) with high nutritive value. The most preferred AIVs by consumers both in urban and peri-urban markets are the Solanacea family (Seremba et al., 2017). The most traded and produced Solanacea vegetables include Solananum aethopicum- shum groups locally known as Nakati (Kabod et al, 2018). Consumption of S. aethiopicum is increasingly becoming the mainstay of traditional diets for millions of Ugandans with the vitamins and minerals needed to maintain health and fight off infections (Ssekuliya et al., 2017).

Besides being a nutritive food crop, S. aethiopicum is now a crop of considerable commercial importance 
with a very high demand both in the local and regional markets (Rubaihayo et al., 2003). The crop ranked third in traded commodities in Ugandan markets during 2015 after vegetables and maize (Wakholi et al.,2015) this confirms Apolot et al (2017) observation that traditional vegetables are increasingly becoming more competitive relative to other non-traditional cash crops. Studies by MAAIF (2014)) revealed that S. aethiopicum can earn farmers over USD 1800 per acre compared to maize which earns them USD 80 for the same area. The current government policy is to diversify exports and introduce non-traditional cash crops into the money economy. In this regard AIVs present a great economic potential (The Monitor, 2016). Because of this importance, it is considered a high priority crop in the National Agricultural Research Strategy and Development Plan (MAAIF, 2014).

Despite the general consumption appeal of $S$. aethiopicum as a popular staple vegetable, a number of production and post-production constraints limit realization of its potential. Unfortunately large quantities $S$. aethiopicum (Nakati) are lost in the entire vegetable supply value chains. Reducing these losses would increase the amount of food available for human consumption and enhance food security, as well as increasing the real income for all the consumers (World Bank, 2011). In Uganda, Agona and Muyinza (2008) reported that up to $40 \%$ of the food that is grown is never eaten because of damage, rotting, pests, and the consumers' demand for perfect produce. Generally, fresh produce losses are higher than those of processed food. For example, Wakholi et al. (2015) registered losses in leafy vegetables in excess of $70 \%$. This comes on heels of poor consumption patterns for vegetables in Uganda. The national average consumption of vegetables and fruits is approximated at $80 \mathrm{~g} /$ person/day, which is far below the world health organisation (WHO) recommended minimum intake of 490g/person/day (FAO, 2014; Wakholi et al., 2015).

Search in literature indicate that significant focus and resources have been allocated to increasing food production (Kader 2005; Kader and Roller 2004). Studies show that 95\% of the research investments during the past 30 years were focused on increasing productivity and only 5\% directed towards reducing losses (Kader and Roller 2004). Increasing agricultural productivity is critical for ensuring global food security, but this may not be sufficient. Food production is currently being challenged by limited land, water and increased weather variability due to climate change. To sustainably achieve the goals of food security, food availability needs to be also increased through reductions in the post-harvest process at farm, retail and consumer levels.

Food losses do not merely reduce food available for human consumption but also cause negative externalities to society through costs of waste management, greenhouse gas production, and loss of scarce resources used in their production.

Post-harvest Food Loss (PHL) is defined as measurable qualitative and quantitative food loss along the supply chain, starting at the time of harvest till its consumption or other end uses (Hodges et al., 2011). PHLs can occur either due to food waste or due to inadvertent losses along the way. Thus, food waste is the loss of edible food due to human action or inaction such as throwing away wilted produce, not consuming available food before its expiry date, or taking serving sizes beyond one's ability to consume. Food loss on the other hand, is the inadvertent loss in food quantity because of infrastructure and management limitations of a given food value chain. Food losses can either be the result of a direct quantitative loss or arise indirectly due to qualitative loss.

Given the significant role food loss reductions could have toward sustainably contributing to global food security, it is important to have reliable measures of these losses. Unfortunately, most of the available postharvest loss and food waste estimates are based on the anecdotal stories with few actual measured or estimated numbers. Traditionally, food losses are first measured at the primary production level by estimating losses from farm-to-retail level. The next is losses at the retail level such as supermarkets, convenience sand grocery stores. Consumer level losses such as homes, restaurants and other foodservice outlets are not incorporated.

Therefore, a robust food losses measurement that provides reliable information for analyses and policy making is needed. In light of this need, this research attempted to empirically quantify physical and economic losses of one popular vegetable $S$. aethiopicum which is also highly perishable. There are very few studies undertaken in Uganda that have sought to quantify the level of leafy vegetable postharvest product loss. Little is known regarding current levels of S.aethiopicum postharvest losses, the contributing risk factors, or the perception supply chain actors in regard to vegetable losses. The specific objectives of this research were to; (1) identify and map the value chain actors of S. aethiopicum (Nakati) vegetable production and marketing. (2) quantify the physical losses along the $S$. aethiopicum vegetable supply chain and (4) estimate the economic losses along the $S$. aethiopicum vegetable supply chain.

\subsection{METHODOLOGY}

This research adopted a case study approach of four S. aethiopicum (Nakati) farming communities and how these products move from the community to one major Kampala city markets. The study largely conducted primary research by considering quantitative and qualitative issues. This section presents research design, research area 
description, research tools, data collection methods and data analysis.

\subsection{Research Design}

This research adopted a detailed case study of postharvest processes and associated losses along a commercial small holder farm-to-market supply chain in Uganda. It is the first systematic quantification of postharvest $S$. aethopicum losses undertaken in Uganda in general. The study tracked and weighed S. aethiopicum (Nakati) at production, harvesting, transportation, handling and marketing of S. aethiopicum from 4 farms in Wakiso district central Uganda to Kampala city markets.

\subsection{Area description}

This study is a case study of four commercial smallholder farms located in Namulonge, Kabanyoro, Busukuma and Zirobwe villages in Wakiso district. The study was carried out in four villages in two sub counties of Nangabo and Busukuma of central Uganda. This is the main Nakati growing region in Uganda, and is located at about $0^{\circ} 28^{\prime} \mathrm{N}$ and $32^{\circ} 27^{\prime} \mathrm{E}$, and northeast of Kampala. The area receives bimodal rainfall, with March-June and October-November as the usual wettest months. The annual rainfall in the area is between 1200-1300 mm. The average maximum and minimum temperatures are about 28.3 and $16.2{ }^{\circ} \mathrm{C}$, respectively, and mean relative humidity ranges from 72 to $93 \%$.

Farm and market participatory loss studies were conducted between September and December 2016 in in Namulonge, Kabanyoro, Zirobwe and Zirobwe villages in Wakiso district while market level study losses were conducted in Owino market one of the largest vegetable markets in Kampala city authority (KCCA). The farmto-market supply chain was selected to ensure farm production practices, postharvest storage and handling, and mode of transport to market were typical of the majority of smallholder farmers.

\subsection{Data Collection Methods}

The study employed several methods to generate different but complementary kinds of data and information. These included primary sources such as participatory rural appraisals (PRA) with key informants and discussions with farmers groups, traders and transporters as well as farmers using standardized structured questionnaire and interview guides.

A PRA was conducted at Namulonge, Kabanyoro, Busukuma and Zirobwe villages on $7^{\text {th }}$ August 2016, $9^{\text {th }}$ August 2016, $10^{\text {th }}$ August 2016 and $12^{\text {th }}$ August 2016, respectively with the farmers to understand the $S$. aethiopicum actors' perception of Nakati vegetable losses and mitigating solutions. The participants through participatory discussions were probed to provide the sources of livelihood in their communities and requested to rank giving number 1 to the most important source of livelihood. A pre-tested semi-structured questionnaire was used to generate the appropriate data. The questions probed included, the constraints encountered in production of S. aethiopicum and the contribution of men and women to overcoming the specific production constraints. The farmers were asked to rank their production constraints with rank 1 being given to the greatest constraint, according to the individual farmers. The percentage of farmers who gave a particular rank to a specific constraint was computed for each constraint, as well as those who did not mention it as a production constraint and, hence, did not attach any rank to it. The interviews were conducted over a period of two months, which coincided with the off-season for rain-fed S. aethiopicum Nakati production. This is the time when the farmers in the area were not too busy with crop production although some of them were involved in production of irrigated $S$. aethiopicum in swamps or involved in seedbed preparation for the following season's crop. Only farmers who were actively involved in $S$. aethiopicum production were considered for this research. This list was provided by the Local Council leaders in the area, and the respondents were randomly selected from that list.

\subsection{Estimating the losses along the S. aethiopicum supply chain}

At farm level, the harvested fresh S. aethiopicum were tied in bundles and each bundle weighed and recorded (A). Then the vegetables that were not removed from garden gathered (B) in addition to those which could not be loaded onto trucks (C) were weighed. The field level losses were determined as a percentage of those that never went to market with total potential from the garden.

Farm level loss $=\boldsymbol{x}=\mathbf{1 0 0} * \frac{(\mathrm{A}+\mathrm{B})}{(\mathbf{A}+\mathbf{B}+\mathbf{C})}$

Where; A is harvested S. aethiopicum (kgs), B is $S$. aethiopicum that remained in the garden $(\mathrm{kgs}), \mathrm{C}$ is $S$. aethiopicum that was harvested but never qualified for loading onto trucks (kgs) and $\boldsymbol{x}_{\text {S. aethiopicum loss (\%) }}$ From the harvested S. aethiopicum vegetables, one bundle $(130 \mathrm{kgs})$ was weighed, marked and tagged at farm level, then followed through transportation to wholesale market, once it was bought it was weighed again to ascertain the whole sale purchase weight, at wholesale level, the wholesale traders remove damaged, soiled and wilted leaves; then these rejects were weighed, the new bundle is also weighed. The retailers who bought these 
bundles for breaking to small quantities were also followed to their stalls, the bundle is weighed at retail point of sale, the leaves and the rejects from the bundle due to cleaning, sorting, grading, wilting, soiling were weighed.

\subsection{Data analysis}

Data were coded and entered into Microsoft Excel computer data spread sheets. Data were closely and rigorously scrutinized for erroneous values that could have occurred during entry. Where values were missing or outrageous, data errors were promptly corrected by referring back to the data check list. Before analysis, data were subjected to reliability tests by visual check and box and whisker plots for missing and extreme values and were addressed accordingly. Descriptive statistics of weighed bundles before and after at each market level as well as the field level losses determined as a percentage of those that never went to market with total potential from the garden performed by comparison of means by Mann-Whitney tests. In all the analyses, the SPSS software was used and significance level of 0.1 was used unless otherwise stated.

\subsection{RESULTS AND DISCUSSION}

This section presents results of mapping Nakati value chain actors,

\subsection{Nakati Vegetable value chain actors}

The Nakati Vegetable value chain actors comprised of input providers, producers, assemblers, processors and traders, who then sell to consumers. Table 1 presents the steps involved in different stages of the Nakati vegetable value chain in central Uganda, the agents playing the different roles, their functions at each stage and the outputs at the different stages of the chain

Table1: Mapping the functions of actors in the $S$. aethopicum vegetable value Chain

\begin{tabular}{|c|c|c|c|c|c|}
\hline Node & In puts & Production & Assembling & Processing & Trading \\
\hline Actors & $\begin{array}{l}\text { - Seed } \\
\text { Companies } \\
\text { - NGOs }\end{array}$ & $\begin{array}{l}\text { - Individuals } \\
\text { - Farmer } \\
\text { groups }\end{array}$ & $\begin{array}{l}\text { - Village assemblers } \\
\text { - Middlemen }\end{array}$ & $\begin{array}{l}\text { - Food industry } \\
\text { - Herbal } \\
\text { industry }\end{array}$ & $\begin{array}{l}\text { - Wholesalers } \\
\text { - Retailers }\end{array}$ \\
\hline Functions & $\begin{array}{l}\text { - Farm } \\
\text { implements } \\
\text { - Farm } \\
\text { equipment } \\
\text { - Chemicals } \\
\text { - fertilizers }\end{array}$ & $\begin{array}{l}\text { - Land } \\
\text { preparation } \\
\text { - Planting } \\
\text { - Weeding } \\
\text { - Harvesting, } \\
\text { - Threshing, } \\
\text { - Packaging }\end{array}$ & $\begin{array}{l}\text { - Bulking } \\
\text { - Transporting } \\
\text { - Marketing } \\
\text { behalf } \\
\text { producers }\end{array}$ & $\begin{array}{ll}\text { - } & \text { Sorting, } \\
\text { Washing } \\
\text { - } & \text { Milling } \\
\text { - } & \text { Quality } \\
\text { control } \\
\text { - } & \text { Packaging }\end{array}$ & $\begin{array}{l}\text { - } \text { Transporting } \\
\text { - Sorting, } \\
\text { - Storage } \\
\text { - Selling to final } \\
\text { consumer }\end{array}$ \\
\hline
\end{tabular}

The focus group discussions at Namulonge, Busukuma, Zirobwe and Kabanyoro identified several Nakati value chain actors in central Uganda that are presented in figure 1.

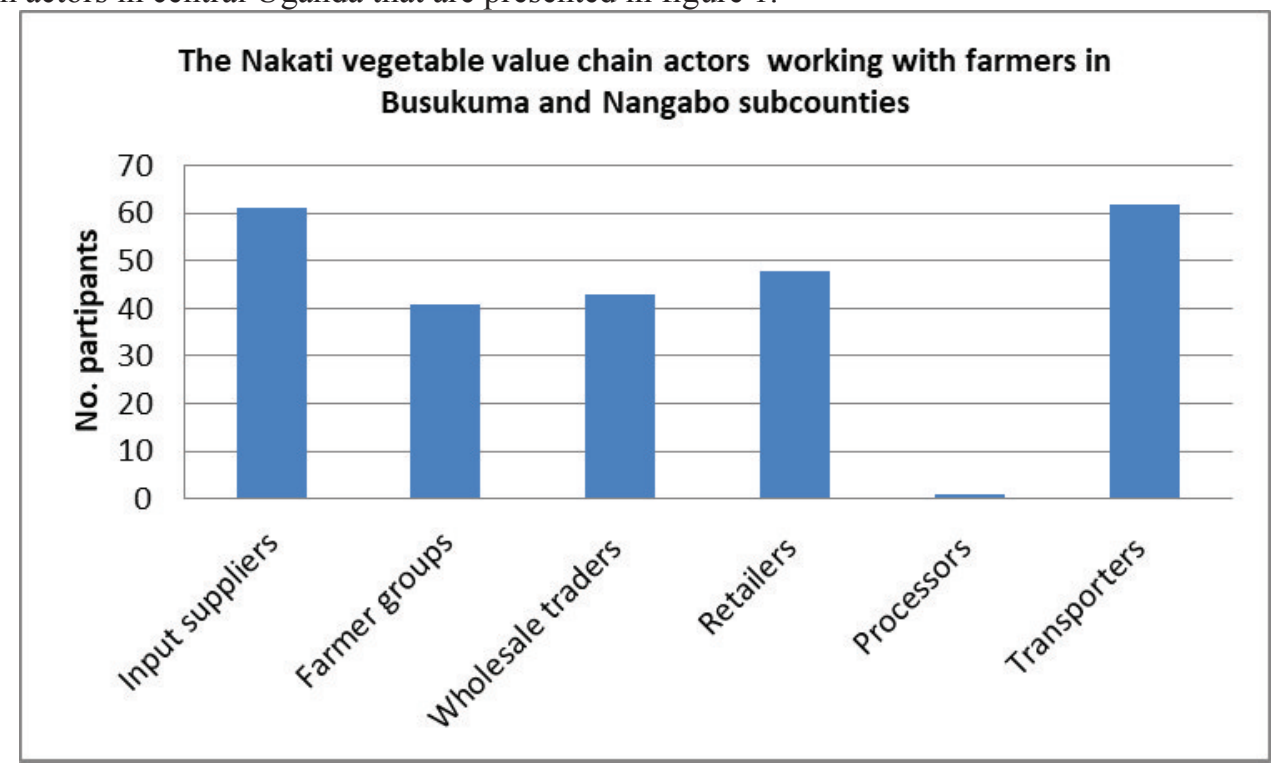

Figure 1: Mapping actors in the Nakati vegetable value Chain

\subsubsection{Input supply node:}

Suppliers of inputs for S. aethiopicum value chain include: seed companies, urban/ rural agro input dealers mostly registered under UNADA, some government programmes like NAADs and NGOS like World Vision 
among others. Their sources of inputs are varied and most are imported from Kenya, China, India, and South Africa. Most of the suppliers operate in the main towns across the country and import most of the inputs they sell other than seed with certification from MAAIF. Some agro dealers may choose to be members of UNADA, an umbrella body where they benefit from training.

\subsubsection{Nakati production node:}

Nakati producers are small scale and subsistence in nature tilling an average of 0.25 ha to 1 ha. Their production is characterized by low input use especially seed and pesticides with most of the producers using seed from previous harvest. The small-scale producers carry out production and post-harvest handling such as harvesting, sorting, cleaning and packaging in bundles of $130 \mathrm{kgs}$. The producers sell their Nakati vegetables to middlemen/village collectors at farm gate who aggregate and eventually transport to major town and Municipal markets in Kampala.

All the interviewed groups were registered with $70 \%$ of them being registered as Community Based Organizations (CBOs) and the rest as cooperatives. On average, these groups have been in existence for close to 3 years with membership ranging from 10 to 33 members. Among the activities undertaken by the producer groups are collective production, collective marketing, transport, capacity building trainings, and access to credit and inputs. The least collectively done activity was primary processing of processing. This was carried out by one producer group in Namulonge which was producing vegetable flour and mixing with bean recipes to make infant foods food.

Apart from production of fresh vegetable for the end markets, some producer groups in Busukuma and Namulonge are involved in the production and multiplication of seed seeds for Simlaw Seed Company as well as for other farmers interested in QDS in collaboration with NaCCRI - Horticultural Research Program at Namulonge.

\subsubsection{Village assemblers/middlemen:}

These move around on bicycles and motorcycles collecting beans from the producers. The village assemblers in most cases are traders who buy Nakati and sell them to large scale traders with 5 MT trucks or transport the Nakati vegetables to major towns where big traders are concentrated. On the other hand, village assemblers can act as agents working on behalf of big traders for a commission. They collect and bulk Nakati vegetables from different farmers especially during off season and receive a commission ranging from UGX $50 / \mathrm{Kg}$ to UGX $100 / \mathrm{Kg}$. Village collectors' play an important role in the Nakati vegetable value chain, the collectors have strong linkages with the producers and in many times they originate from the producing areas and thus know the sources of vegetables but are also trusted more by the producers. The collectors plays link role between producers and big buyers of vegetables. In this study it was revealed that producers sell $69 \%$ of the of their fresh Nakati vegetables to village collectors and brokers and only $5 \%$ is retained for home consumptions, seed and handouts. The remaining 26\% is sold directly to processors (Kayebe Sauce Packers,) and institutional buyers such as schools (Figure 2).

\section{Distribution and Flow of Produced Nakati}

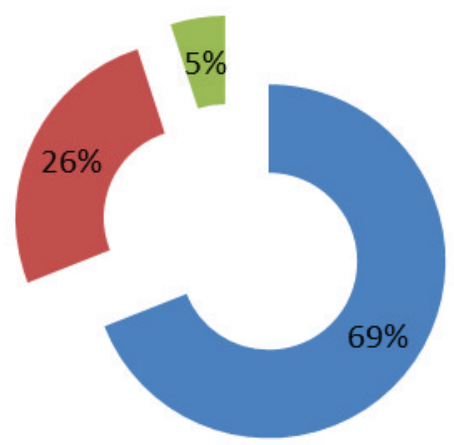

- Village Collectors $\square$ Institutional and processors $\quad$ Hand outs and home use

Figure 2: Quantification of Physical flows in the Nakati vegetable value chain

\subsubsection{Market Wholesalers:}

Even though value addition of Nakati vegetables in Uganda is limited, trade in fresh vegetables is expanding due to expanding markets in most urban areas. In this study, a total of 46 wholesale traders were interviewed from markets where Nakati is traded. About $53 \%$ of the respondents had legally registered their businesses. Nakati 
vegetables are generally traded as fresh $(98 \%)$ and with $2 \%$ of the traded Nakati being processed at wholesale level. The main buyers of Nakati vegetables from wholesale traders are fellow wholesale traders, retail traders, schools and hotels.

\subsubsection{Retailers:}

About $9 \%$ of retailers interviewed were from Owino market, $22 \%$ from Kalerwe and 11\%from Nakasero while $15 \%$ were from Nakawa market. The Nakati vegetable retailers handled other commodities such as tomatoes, egg plants and cabbages. Most of the respondents had registered their businesses with $60 \%$ running them on full time basis while $40 \%$ had employed sales people and/or managers to run their businesses.

Nakati retailers operate mainly from small shops and open markets as well as supermarkets. Small shops and open markets mainly deal with different vegetables while supermarkets well packaged vegetables though handle small quantities. The retailers are involved in activities such as transportation from wholesalers' premises to their premises and packaging before selling to the final consumers.

\subsubsection{Processors:}

These transform vegetables into different products. An example is Kayebe Sauce Packers (U) Ltd which processes Nakati flour. The process usually involves testing for moisture content and drying, sorting, washing, extrusion and milling. Final quality control checks are then done before packaging. The processor (Kayabe Sauce Packers) procures Nakati Vegetables from farmers and open markets and a few selected individual traders. The flour is packaged in 500g packs and sold to supermarkets such as Capital shoppers, Tuskys and NOGAMU. Production of processed Nakati products is however still low given the low demand and at times the products are produced on demand.

\subsection{Quantifying Losses along the S.aethopicum vegetable Supply Chain}

Postharvest handling of $S$. aethopicum vegetables from the production farms to the selling markets results in quantitatively high wastages. In the present study, between the point of harvest and arrival at the municipal markets (Tables 2 and 3) a substantial quantity never reached the consumers. Although the quantities of $S$. aethopicum harvested varied in different farms, on average of the $1473.3 \mathrm{kgs}$ of $S$. aethopicum harvested, $69.4 \mathrm{kgs}$ and $73.7 \mathrm{kgs}$ got lost in the field and marketing process, respectively. This translates into S. aethopicum vegetable losses of $13.3 \%$ and $5.2 \%$ in the field and market points, respectively. Overall, $143.1 \mathrm{kgs}$ of the harvested $S$. aethopicum vegetable crop was removed from the commercial supply chain through losses (Tables 2 and 3 ).

Most of this loss occurred on-farm, with $13.3 \%$ of the harvested crop not entering the commercial-supply chain (Table 2). Postharvest loss at field level was primarily attributed to poor harvesting practices that leave some vegetables in the garden $(3 \%)$, bruises and injuries $(9.3 \%)$, sorting $(0.8 \%)$ and physical dropping during transit to collection centres $(0.8 \%)$.

Table 2: Quantifying physical field losses of S. aethopicum supply chain in Uganda

\begin{tabular}{|c|c|c|c|c|c|}
\hline \multirow[t]{2}{*}{ Aspect } & \multicolumn{5}{|c|}{ Material source } \\
\hline & Namulonge & Zirobwe & Kabanyoro & Busukuma & overall \\
\hline Number of S. aethopicum bundles harvested & 12.0 & 13.5 & 10.5 & 9.4 & 11.3 \\
\hline Amount of $S$. aethopicum harvested (Kgs) & 1560.0 & 1750.7 & 1365.0 & 1217.7 & 1473.3 \\
\hline Size of land harvested (acres) & 0.3 & 0.5 & 0.6 & 0.4 & 0.4 \\
\hline S. aethopicum output Kgs/acre & 4936.4 & 3873.5 & 4767.0 & 3680.9 & 4314.5 \\
\hline Amount of S. aethopicum $(\mathrm{kg})$ left in the field & 30.9 & 54.6 & 62.6 & 29.5 & 44.4 \\
\hline$\%$ loss output (left in field) & 2.0 & 3.0 & 4.5 & 2.4 & 3.0 \\
\hline $\begin{array}{l}\text { Amount of } S \text {. aethopicum lost due to bruises } \\
\text { and injuries (Kgs) }\end{array}$ & 8.7 & 9.2 & 11.0 & 10.8 & 9.9 \\
\hline \% losses & 9.6 & 4.0 & 4.7 & 18.8 & 9.3 \\
\hline Amount of S. aethopicum lost in sorting (Kgs) & 3.2 & 3.1 & 3.3 & 4.0 & 3.4 \\
\hline$\%$ losses & 0.2 & 0.2 & 0.2 & 0.3 & 0.2 \\
\hline $\begin{array}{l}\text { Amount of } S \text {. aethopicum lost in transit to } \\
\text { collection centres (Kgs) }\end{array}$ & 10.9 & 11.3 & 12.6 & 11.8 & 11.7 \\
\hline$\%$ losses & 0.7 & 0.7 & 0.9 & 1.0 & 0.8 \\
\hline $\begin{array}{l}\text { Total amount of } S \text {. aethopicum lost in the field } \\
\text { (Kgs) }\end{array}$ & 53.7 & 78.2 & 89.5 & 56.1 & 69.4 \\
\hline$\%$ Field loss & 12.6 & 7.8 & 10.4 & 22.5 & 13.3 \\
\hline
\end{tabular}

Comparatively, though market level losses were lower than field level losses, nevertheless more than 73.7 $\mathrm{kgs}$ of S. aethopicum vegetables were removed from the vegetable supply chain at wholesale and retail market levels (Table 5). Wholesale level losses are responsible for the $1.7 \%$ of losses incurred in the entire supply chain. These losses are contributed by; transit losses $(0.2 \%)$, bruises $(0.7 \%)$ and offloading and left overs in trucks $(0.2 \%)$. 
On the other hand, at retail level, $69.4 \mathrm{~kg}$ of $S$. aethopicum is lost from the supply chain which translates into $3.5 \%$ losses (Table 3). This study found that the contributors of this loss include; transit losses $(0.5 \%)$, contamination with foreign matter $(0.5 \%)$ and sorting and grading $(2.5 \%)$ as indicated in Table 3.

Table 3: Quantifying physical market and transit losses of $S$. aethopicum supply chain in central Uganda

\begin{tabular}{|c|c|c|c|c|c|}
\hline \multirow[t]{2}{*}{ Loss aspect } & \multicolumn{5}{|c|}{ S. aethopicum source } \\
\hline & Namulonge & Zirobwe & Kabanyoro & Busukuma & overall \\
\hline $\begin{array}{l}\text { Amount of } S \text {. aethopicum lost in transit } \\
\text { from collection points to Kalerwe market (Kgs) }\end{array}$ & 13.0 & 12.2 & 11.6 & 10.0 & 11.7 \\
\hline \% losses & 0.9 & 0.7 & 0.8 & 0.8 & 0.8 \\
\hline $\begin{array}{l}\text { Amount of } S . \text { aethopicum lost in Kalerwe due } \\
\text { to bruises }(\mathrm{Kgs})\end{array}$ & 11.1 & 10.0 & 9.4 & 8.1 & 9.6 \\
\hline \% losses & 0.7 & 0.6 & 0.7 & 0.7 & 0.7 \\
\hline $\begin{array}{l}\text { Amount of } S \text {. aethopicum lost due offloading } \\
\text { and remains in the trucks (Kgs) }\end{array}$ & 3.4 & 3.3 & 2.4 & 1.9 & 2.8 \\
\hline \% losses & 0.2 & 0.2 & 0.2 & 0.2 & 0.2 \\
\hline $\begin{array}{l}\text { Total amount of } S \text {. aethopicum lost at whole } \\
\text { sale level (Kgs) }\end{array}$ & 27.5 & 25.5 & 23.4 & 20.0 & 24.1 \\
\hline$\%$ wholesale level loss & 1.8 & 1.5 & 1.7 & 1.7 & 1.7 \\
\hline $\begin{array}{l}\text { Amount of } S \text {. aethopicum lost in transit } \\
\text { from Kalerwe wholesalers to Mulago retailers } \\
(\mathrm{Kgs})\end{array}$ & 8.1 & 6.7 & 7.0 & 5.3 & 6.8 \\
\hline \% losses & 0.5 & 0.4 & 0.5 & 0.5 & 0.5 \\
\hline $\begin{array}{l}\text { Amount of } S \text {. aethopicum lost at Mulago } \\
\text { retail market due to foreign matter }\end{array}$ & 7.3 & 6.1 & 9.0 & 6.9 & 7.3 \\
\hline \% losses & 0.5 & 0.3 & 0.7 & 0.6 & 0.5 \\
\hline $\begin{array}{l}\text { Amount of } S \text {. aethopicum lost at Mulago } \\
\text { retail market due to sorting and grading (Kgs) }\end{array}$ & 34.7 & 32.2 & 40.8 & 34.2 & 35.5 \\
\hline \% losses & 2.3 & 1.9 & 3.0 & 2.8 & 2.5 \\
\hline $\begin{array}{l}\text { Total amount of } S \text {. aethopicum lost at retail } \\
\text { level (Kgs) }\end{array}$ & 50.2 & 45.0 & 56.8 & 46.4 & 49.6 \\
\hline$\%$ retail level losses & 3.3 & 2.6 & 4.2 & 3.9 & 3.5 \\
\hline
\end{tabular}

The present combined $S$. aethopicum vegetable losses of $17.5 \%$ both in the field and market points are high for a country like Uganda which experiences high incidences of malnutrition. These losses compare well with other vegetable studies done globally. Gorny (2001) estimated that between 10 to $40 \%$ of the vegetables grown are never eaten because of damage, rotting, pests, and the consumers' demand for "perfect" produce. While working in China, Zengh et al (2001) reported losses of $16 \%$ and $14.5 \%$ on cabbage and broccoli vegetables, respectively. The plausible explanation for such losses was that vegetables are living, breathing parts of plants and contain 65 to 95\% water (Sekulya et al, 2018). Once harvested their internal food and water reserves decline over time and vegetables deteriorate and rot (Apolot et al, 2018). Anything that increases the rate at which food and water reserves are used up increases the rate of deterioration. Acceleration of deterioration can be due to high temperature, low humidity, incorrect atmosphere and/ or physical damage. Sekulya et al (2018) while working on S. aethiopicum (Shum) in Uganda observed that leafy type vegetables have a high moisture content which gives them a short shelf life. On average has a shelf life of one day, making it unable to keep fresh for a long time.

However, vegetable losses in this study were lower than $32.9 \%$ recorded on tomatoes in Australia (Underhill and Kumar, 2015) and 40\% on Amaranthus in Uganda (Agona and Muyinza, 2008) as well as 70\% on spinach (Wakholi et al. (2015). This confirms Parfitt, et al., (2010), Gustavsson, et al., (2011) and Rockefeller Foundation (2013) observations that food losses vary depending on location and handling systems. The complexity is reflected through the various dimensions of food losses; (i) time (ii) space (iii) nature. A last issue is the complexity of food losses which may be quantitative or qualitative. Food losses can be quantitative as measured by decreased weight or volume, or can be qualitative, such as reduced nutrient value and unwanted changes to taste, color, texture, or cosmetic features of food (Buzby and Hyman, 2012). The quantitative loss is caused by the reduction in weight due to factors such as spillage, consumption by pest and also due to physical changes in temperature, moisture content and chemical changes (FAO, 2014). The qualitative loss can occur due to incidence of insect pest, mites, rodents and birds, or from handling, physical changes or chemical changes in fat, carbohydrates and protein, and by contamination of mycotoxins, pesticide residues, insect fragments, or excreta of rodents and birds and their dead bodies.

The inconsistency in the levels of losses points to the need to understand the physiological properties of the 
different vegetable species. Notwithstanding the differing rates of vegetable losses along the supply value chain, offsetting such losses would significantly contribute to the strategy of availing food without resorting to opening more land by focusing on increasing crop yields using a variety of input management practices and high-yielding nutrient-rich cultivars (FAO, 2014; Bradford et al., 2018). Increasing yields to the required extent may be difficult in many climates and locations, particularly in the face of strained economic and environmental resources (Lobell et al., 2009).

\subsection{Estimating economic Losses along the S. aethopicum vegetable Supply Chain}

Postharvest handling of $S$. aethopicum vegetables from the production farms to the selling markets contribute to reduced and ultimately low farm incomes. In this study, economic losses occur at the point of harvest and arrival at the markets (Tables 4 and 5) significant revenue is never earned by farmers and traders in the S. aethopicum vegetable supply chain. Although sell of S. aethopicum earned farmers 567,233 Shs, sizeable revenue of 26,700 Shs and 53,192 Shs get lost in the field and marketing process, respectively. This is equivalent to S. aethopicum revenue losses of $18 \%$ and $35.9 \%$ in the field and market points, respectively. Overall, 79,892 Shs of $S$. aethopicum revenues was lost in the commercial supply chain (Tables 4 and 5) constituting 53.9\% of the losses. Break down of revenue loss at farm level is $18 \%$ (Table 4). This is primarily attributed to poor harvesting practices that leave some vegetables in the garden that contributes the revenue loss of $11.5 \%$, bruises and injuries account for $2.6 \%$ of lost revenue, while sorting leads to $0.9 \%$ revenue loss and physical dropping of $\mathrm{S}$. aethopicum vegetables during transit to collection centres contributes $3.0 \%$ of revenue losses.

Table 4: Quantifying economic field losses of $S$. aethopicum supply chain in central Uganda

\begin{tabular}{|c|c|c|c|c|c|}
\hline \multirow[t]{2}{*}{ Loss aspect } & \multicolumn{5}{|c|}{ S. aethopicum source } \\
\hline & Namulonge & Zirobwe & Kabanyoro & Busukuma & overall \\
\hline Number of S. aethopicum bundles sold & 12 & 13 & 11 & 9 & 11 \\
\hline Quantity of S. aethopicum sold (Kgs & 1,560 & 1,751 & 1,365 & 1,218 & 1,473 \\
\hline $\begin{array}{l}\text { Farm gate Price of } S \text {. aethopicum (Shs/ } \\
\mathrm{kg} \text { ) }\end{array}$ & 385 & 385 & 385 & 385 & 385 \\
\hline $\begin{array}{l}\text { Farm Revenues from sale of } S . \\
\text { aethopicum (shs) }\end{array}$ & 600,600 & 674,006 & 525,525 & 468,802 & 567,233 \\
\hline $\begin{array}{l}\text { Amount of } S \text {. aethopicum }(\mathrm{kg}) \text { left in the } \\
\text { field }\end{array}$ & 31 & 55 & 63 & 29 & 44 \\
\hline $\begin{array}{l}\text { Farm Revenues lost because } S \text {. } \\
\text { aethopicum is left in field (Shs) }\end{array}$ & 11,897 & 21,008 & 24,088 & 11,345 & 17,084 \\
\hline$\%$ revenue lost & 8.0 & 14.2 & 16.3 & 7.7 & 11.5 \\
\hline Lost revenues due to bruises (Shs) & 3,337 & 3,545 & 4,235 & 4,167 & 3,821 \\
\hline$\%$ revenue lost & 2.3 & 2.4 & 2.9 & 2.8 & 2.6 \\
\hline Lost revenues due to sorting (Shs) & 1,245 & 1,174 & 1,258 & 1,522 & 1,300 \\
\hline$\%$ revenue lost & 0.8 & 0.8 & 0.8 & 1.0 & 0.9 \\
\hline $\begin{array}{l}\text { Lost revenues during transit to collection } \\
\text { centres (Shs) }\end{array}$ & 4,197 & 4,365 & 4,864 & 4,556 & 4,495 \\
\hline$\%$ revenue lost & 2.8 & 2.9 & 3.3 & 3.1 & 3.0 \\
\hline Total revenues lost at field level (Shs) & 20,675 & 30,092 & 34,445 & 21,590 & 26,700 \\
\hline$\%$ Field revenues lost & 13.9 & 20.3 & 23.2 & 14.6 & 18.0 \\
\hline
\end{tabular}

Significantly, higher revenue losses were registered at marketing points than field level revenue losses (Table 4 and 5). Wholesale level losses are responsible for the $10.2 \%$ of revenue losses incurred in the entire supply chain. These losses are contributed by; transit losses $(4.9 \%)$, bruises $(04.1 \%)$ and offloading and left overs in trucks $(1.2 \%)$.

On the other hand, at retail level, $25.7 \%$ of S. aethopicum revenue is lost from the supply chain (Table 5). This study found that the contributors of this revenue loss include; due to transit losses $(3.5 \%)$, due to contamination with foreign matter (3.8\%) and due to sorting and grading (18.4\%) as indicated in Table 5 . 
Table 4: Quantifying market and transit economic losses of $S$. aethopicum supply chain in central Uganda Loss aspect

\section{S. aethopicum source}

\begin{tabular}{|c|c|c|c|c|c|}
\hline & \\
\hline & Namulonge & Zirobwe & Kabanyoro & Busukuma & overall \\
\hline $\begin{array}{l}\text { Lost revenues during transit from collection } \\
\text { points to Kalerwe market }\end{array}$ & 8,125 & 7,640 & 7,250 & 6,254 & 7,317 \\
\hline$\%$ revenue lost & 5.5 & 5.2 & 4.9 & 4.2 & 4.9 \\
\hline Lost revenues due to bruises (Shs) & 6,938 & 6,267 & 5,854 & 5,063 & 6,030 \\
\hline \% revenue lost & 4.7 & 4.2 & 3.9 & 3.4 & 4.1 \\
\hline $\begin{array}{l}\text { Lost revenues due to offloading and truck } \\
\text { remains }\end{array}$ & 2,125 & 2,048 & 1,521 & 1,188 & 1,720 \\
\hline$\%$ revenue lost & 1.4 & 1.4 & 1.0 & 0.8 & 1.2 \\
\hline Total whole sale level revenue lost & 17,188 & 15,954 & 14,625 & 12,504 & 15,068 \\
\hline \% wholesale level revenue loss & 11.6 & 10.8 & 9.9 & 8.4 & 10.2 \\
\hline $\begin{array}{l}\text { Lost revenues during transit from Kalerwe } \\
\text { market to Mulago retail market }\end{array}$ & 6,255 & 5,152 & 5,357 & 4,065 & 5,207 \\
\hline$\%$ revenue lost & 4.2 & 3.5 & 3.6 & 2.7 & 3.5 \\
\hline Lost revenue due to foreign matter & 5,639 & 4,691 & 6,947 & 5,296 & 5,643 \\
\hline$\%$ revenue lost & 3.8 & 3.2 & 4.7 & 3.6 & 3.8 \\
\hline Lost revenue due to sorting and grading & 26,684 & 24,736 & 31,350 & 26,325 & 27,274 \\
\hline$\%$ revenue lost & 18.0 & 16.7 & 21.1 & 17.8 & 18.4 \\
\hline Total lost revenue at retail level & 38,578 & 34,579 & 43,654 & 35,687 & 38,124 \\
\hline \% retail level revenue loss & 26.0 & 23.3 & 29.5 & 24.1 & 25.7 \\
\hline
\end{tabular}

This study estimates that 79,892 Shs of Nakati revenues were lost in the entire commercial supply chain which is equivalent to $53.9 \%$ of lost revenues. Most of these lost revenues are moderate revenue losses that at each handling stage little money is lost which cumulatively grow into a colossal loss. The economic loss is slow and unobtrusive at first, yet the effects accumulate over time. Not surprisingly farmers underestimate the extent of food loses in the early stages, and that misperceptions are very common. Several interrelated factors explain the prevailing uncertainties around post-harvest economic losses. A first issue is measurability; food loss poses a severe challenge to contemporary scientific methods. There is simply no clear cause - effect relationships (Gustavsson, et al., 2011). When this qualitative deterioration makes food unfit for human consumption and is rejected, this contributes to food loss. Existence of food loss is not necessarily evidence of an economic problem (Kader 2005; Kader and Roller 2004). There would be an economic problem when the costs of food losses outweigh the benefits underlying the loss process. Food loss is likely to be an economic problem when private and social interests do not coincide (Kader and Roller 2004). While most experts agree that food loss incurs some costs, the magnitude of these costs is highly debatable. One particular controversy revolves around the relative importance of on-site and off-site costs (Kader and Roller 2004). Whatever the exact magnitude of value chain node level costs, some are of the opinion, that farm level losses are largely significant than market level losses. However in this study, S. aethopicum market level revenue losses were relatively higher than field level revenue losses. This is attributed to differentials in the prices of $S$. aethopicum at different value chain nodes. The farm gate prices were $385 \mathrm{Shs}$ per $\mathrm{kg}$ of $\mathrm{S}$. aethopicum as compared to $720 \mathrm{Shs}$ per $\mathrm{kg}$ at market level. Food losses do not only reduce food available for human consumption but also cause negative externalities to society through costs of waste management, greenhouse gas production, and loss of scarce resources used in their production.

\section{Conclusion}

The value chain actor mapping has revealed a short a short value chain with a number of value chain actors namely; 60 input suppliers, 40 farmer groups, 42 wholesalers, 48 retailers, 2 processors and 61 transporters.

The study further indicated that the physical quantities of $S$. aethopicum harvested varied in different farms, on average of the $1473.3 \mathrm{kgs}$ of $S$. aethopicum harvested, $69.4 \mathrm{kgs}$ and $73.7 \mathrm{kgs}$ got lost in the field and marketing process, respectively. This translates into S. aethopicum vegetable losses of $13.3 \%$ and $5.2 \%$ in the field and market points, respectively. Most of this loss occurred on-farm with $13.3 \%$ of the harvested crop not entering the commercial-supply chain followed by retail level, 3.5\% losses and least at wholesale level of $1.7 \%$.

In terms of economic loss assessment significant revenue is never earned by farmers and traders in the $S$. aethopicum vegetable supply chain. Although sell of S. aethopicum earned farmers 567,233 Shs per acre, sizeable revenue of 26,700 Shs and 53,192 Shs get lost in the field and marketing process, respectively. This is equivalent to $S$. aethopicum revenue losses of $18 \%$ and $35.9 \%$ in the field and market points, respectively. Overall, 79,892 Shs of S. aethopicum revenues was lost in the commercial supply chain constituting $53.9 \%$ of the losses. Break down of revenue loss at farm level is $18 \%$. Wholesale level losses are responsible for the 
$10.2 \%$ of revenue losses at retail level, $25.7 \%$ of $S$. aethopicum revenue is lost from the supply chain.

It therefore can be concluded that there is a high physical and economic losses of leafy S. aethopicum vegetables at different stages in the supply chain. More research efforts could be focussed on technologies that reduce post-harvest losses such as drying and minimal processing technologies at farm level where greatest losses are experienced.

\section{References}

1. Agona, A., \& Muyinza, H. (2008). An overview of horticulture in Uganda. Kampala, Uganda: Programme, National Agricultural Research Organization.

2. Apolot M.G, J. Ssozi, A.Namutebi1, M. Masanza, Kizito E., Rees D., and Acham H. Changes in Sensory and Quality Characteristics of S. Aethiopicum (Shum) and A. Lividus (Linn) Leafy Vegetables along the Supply Chain. American Journal of Food Science and Technology, 2018, Vol. 6, No. 4, 161-166

3. Bradford K. FAO (2014). Code of practice for the prevention and reduction of mycotoxin contamination in cereals. CAC/RCP 51-2003: Codex AlimentariusFood and Agriculture Organization ofthe United Nationswww.fao.org/fao-who-codexalimentarius/standards/en/.,

4. Buzby, J. C., and H. Jeffrey. 2012. "Total and per capita value of food loss in the United States." Food Policy 37: 561-570.

5. Buzby, J. C., and J. Hyman. 2012. "Total and per capita value of food loss in the United States." Food Policy, 37(5), 561-570.

6. Dahala P., J.Asbrouckb, K.Kunusothc, P.Belloa,J.Thompsond, F. Wue 2018). The dry chain: Reducing postharvest losses and improving food safety in humid climates. Trends in Food Science \& Technology 71 (2018) 84-93

7. FAO (2010) The State of Food Insecurity in the World. UN Food and Agriculture Organisation, Online Available: http://www.fao.org/docrep/013/i1683e/i1683e.pdf

8. Gorny, J.R. 2001. A summary of CA and MA requirements and recommendations for fresh-cut (minimally processed) fruits and vegetables. pp 95-145. Postharvest Horticulture Series No. 22A, University of California, Davis.

9. Gustavsson, J., Cederberg, C., Sonesson, U., Van Otterdijk, R., \& Meybeck, A. (2011). Global food losses and food waste. Rome, Italy: Food and Agriculture Organization of the United Nations.

10. Hodges, R.J., J.C. Buzby, and B. Bennett. 2011 "Postharvest losses and waste in developed and less developed countries: opportunities to improve resource use." Journal of Agricultural Science 149:37-45

11. Kabod N.P, Sseremba G., Buteme R., Masanza .M and Kizito E.B. 2018. Stability for descriptors of Solanum aethiopicum Shum group (family Solanaceae). Journal of Plant Breeding and Crop Science

12. Kader, A.A. 2005. "Increasing food availability by reducing postharvest losses of fresh produce." Acta Horticulture 682:2169-2176.

13. Kader, A.A. and R.S. Rolle. 2004. "The Role of Post-harvest Management in Assuring the Quality and Safety Horticultural Crops". Food and Agriculture Organization. Agricultural Services Bulletin 152, 52 p.

14. Lobell, D. B., Cassman, K. G., \& Field, C. B. (2009). Crop yield gaps: Their importance, magnitudes, and causes. Annual Review of Environment and Resources, 34, 179-204. http://dx.doi.org/10.1146/annurev.environ.041008.093740.

15. MAAIF (2014). Agricultural Sector Development Strategy and Investment Plan. 2010/11- 2014/15.

16. Parfitt, J., Barthel, M., \& Macnaughton, S. (2010). Food waste within food supply chains: Quantification and potential for change to 2050. Philosophical Transactions of the Royal Society of London. Series B: Biological Sciences, 365(1554), 3065-3081. http://dx.doi.org/10.1098/rstb.2010.0126.

17. Rockefeller Foundation (2017). Yield Wise. Reducing post-harvest food loss for African farmers. Retrieved 21 July, 2017, from https:/www.rockefellerfoundation.org/ourwork/ initiatives/yieldwise/.Buzby and Hyman, 2012).

18. Rubaihayo E. B., Hart T., Kakonge E., Kaaya A., Kawongolo J., Kabeere F, Mugisha J, Tumwiine J. and Rubaihayo P.(2003). Development of Mechanisms for Sustainable Production and Utilisation of Indigenous Vegetables and Management of their Genetic Diversity in Uganda.

19. Sekulya S., Nandutu A, Namutebi A., Ssozi J., Masanza M., Jagwe J. N., Kasharu A., Rees D., Kizito E. B., Acham H. Effect of Post-Harvest Handling Practices, Storage Technologies and Packaging Material on Post-Harvest Quality and Antioxidant Potential of Solanum Aethiopicum (Shum) Leafy Vegetable. American Journal of Food Science and Technology, 2018, Vol. 6, No. 4, 167-180

20. Sseremba G., Tongoona P., Eleblu J.S.Y., Danquah E.Y. and Kizito E.B., 2018. Linear Discriminant Analysis of Structure within African Eggplant 'Shum'. African Crop Science Journal, Vol. 26, No. 1

21. Underhill, S.J.R. and Kumar S. (2015). Quantifying postharvest losses along a commercial tomato supply chain in Fiji: A case study. Journal of Applied Horticulture, 17(3): 199-204, 2015

22. Wakholi, C., Cho, B.-K., Mo, C., \& Kim, M. S. (2015). Current State of Postharvest Fruit and Vegetable 
Management in East Africa. Journal of Biosystems Engineering, 40(3), $238-249$. https://doi.org/10.5307/JBE.2015.40.3.238

23. World Bank (2011). Missing food: The case of postharvest grain losses in sub-Saharan Africa. Report Number 60371-AFRWashington, DC: The World Bank. Retrieved 21 July, 2017,from http://www.fao.org/3/a-at454e.pdf.

24. Zheng S., Li W., Gao L., and Wu P. (2001). Postharvest Handling of Fresh Vegetables. edited by Tim O’Hare, John Bagshaw, Wu Li, and Greg Johnson ACIAR Proceedings 105 